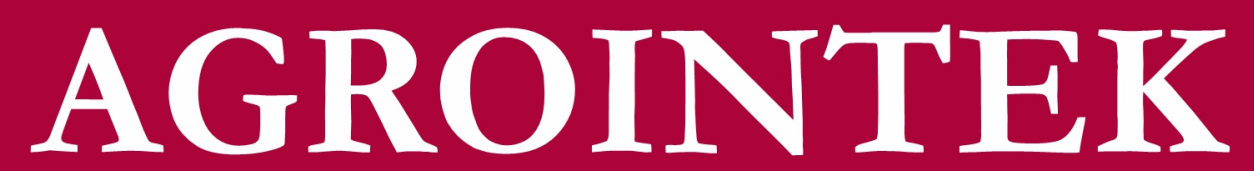

JURNAL TEKNOLOGI INDUSTRI PERTANIAN

JURUSAN TEKNOLOGI INDUSTRI PERTANIAN UNIVERSITAS TRUNOJOYO MADURA 


\title{
AGROINTEK: Jurnal Teknologi Industri Pertanian
}

Agrointek: Jurnal Teknologi Industri Pertanian is an open access journal published by Department of Agroindustrial Technology,Faculty of Agriculture, University of Trunojoyo Madura. Agrointek: Jurnal Teknologi Industri Pertanian publishes original research or review papers on agroindustry subjects including Food Engineering, Management System, Supply Chain, Processing Technology, Quality Control and Assurance, Waste Management, Food and Nutrition Sciences from researchers, lecturers and practitioners. Agrointek: Jurnal Teknologi Industri Pertanian is published four times a year in March, June, September and December.

Agrointek does not charge any publication fee.

Agrointek: Jurnal Teknologi Industri Pertanian has been accredited by ministry of research, technology and higher education Republic of Indonesia: 30/E/KPT/2019. Accreditation is valid for five years. start from Volume 13 No 2 2019.

\section{Editor In Chief}

Umi Purwandari, University of Trunojoyo Madura, Indonesia

\section{Editorial Board}

Wahyu Supartono, Universitas Gadjah Mada, Yogjakarta, Indonesia

Michael Murkovic, Graz University of Technology, Institute of Biochemistry, Austria

Chananpat Rardniyom, Maejo University, Thailand

Mohammad Fuad Fauzul Mu'tamar, University of Trunojoyo Madura, Indonesia

Khoirul Hidayat, University of Trunojoyo Madura, Indonesia

Cahyo Indarto, University of Trunojoyo Madura, Indonesia

\section{Managing Editor}

Raden Arief Firmansyah, University of Trunojoyo Madura, Indonesia

\section{Assistant Editor}

Miftakhul Efendi, University of Trunojoyo Madura, Indonesia

Heri Iswanto, University of Trunojoyo Madura, Indonesia

Safina Istighfarin, University of Trunojoyo Madura, Indonesia

\author{
Alamat Redaksi \\ DEWAN REDAKSI JURNAL AGROINTEK \\ JURUSAN TEKNOLOGI INDUSTRI PERTANIAN \\ FAKULTAS PERTANIAN UNIVERSITAS TRUNOJOYO MADURA \\ Jl. Raya Telang PO BOX 2 Kamal Bangkalan, Madura-Jawa Timur \\ E-mail: Agrointek@trunojoyo.ac.id
}




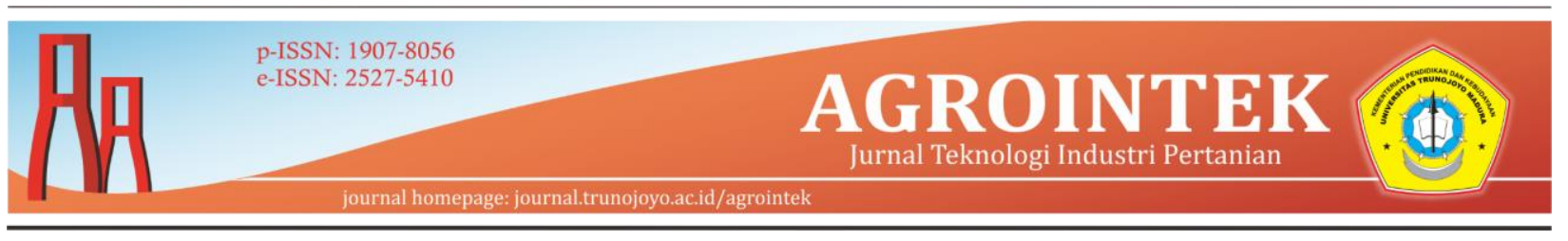

\section{KATA PENGANTAR}

Salam,

Dengan mengucap syukur kepada Allah Tuhan Yang Maha Esa, kami terbitkan Agrointek edisi September 2021. Di tengah pandemi yang berkepanjangan ini, ilmuwan Indonesia masih tetap berkarya. Pada edisi kali ini 32 artikel hasil penelitian, yang terdiri dari 11 artikel dari bidang pengolahan pangan dan nutrisi, sistem manajemen, rantai pasok, dan pengendalian kualitas; 3 artikel tentang rekayasa pangan, dan 2 artikel tentang manajemen limbah. Para penulis berasal dari berbagai institusi pendidikan dan penelitian di Indonesia.

Kami mengucapkan terima kasih kepada para penulis dan penelaah yang telah bekerja keras untuk menyiapkan manuskrip hingga final. Kami juga berterimakasih kepada ibu dan bapak yang memberi kritik dan masukan berharga bagi Agrointek.

Untuk menyiapkan peringkat jurnal Agrointek di masa depan, kami mengharap kontribusi para peneliti untuk mengirimkan manuskrip dalam bahasa Inggris. Semoga kita akan mampu menerbitkan sendiri karya-karya unggul para ilmuwan Indonesia.

Selamat berkarya.

Salam hormat

Prof. Umi Purwandari
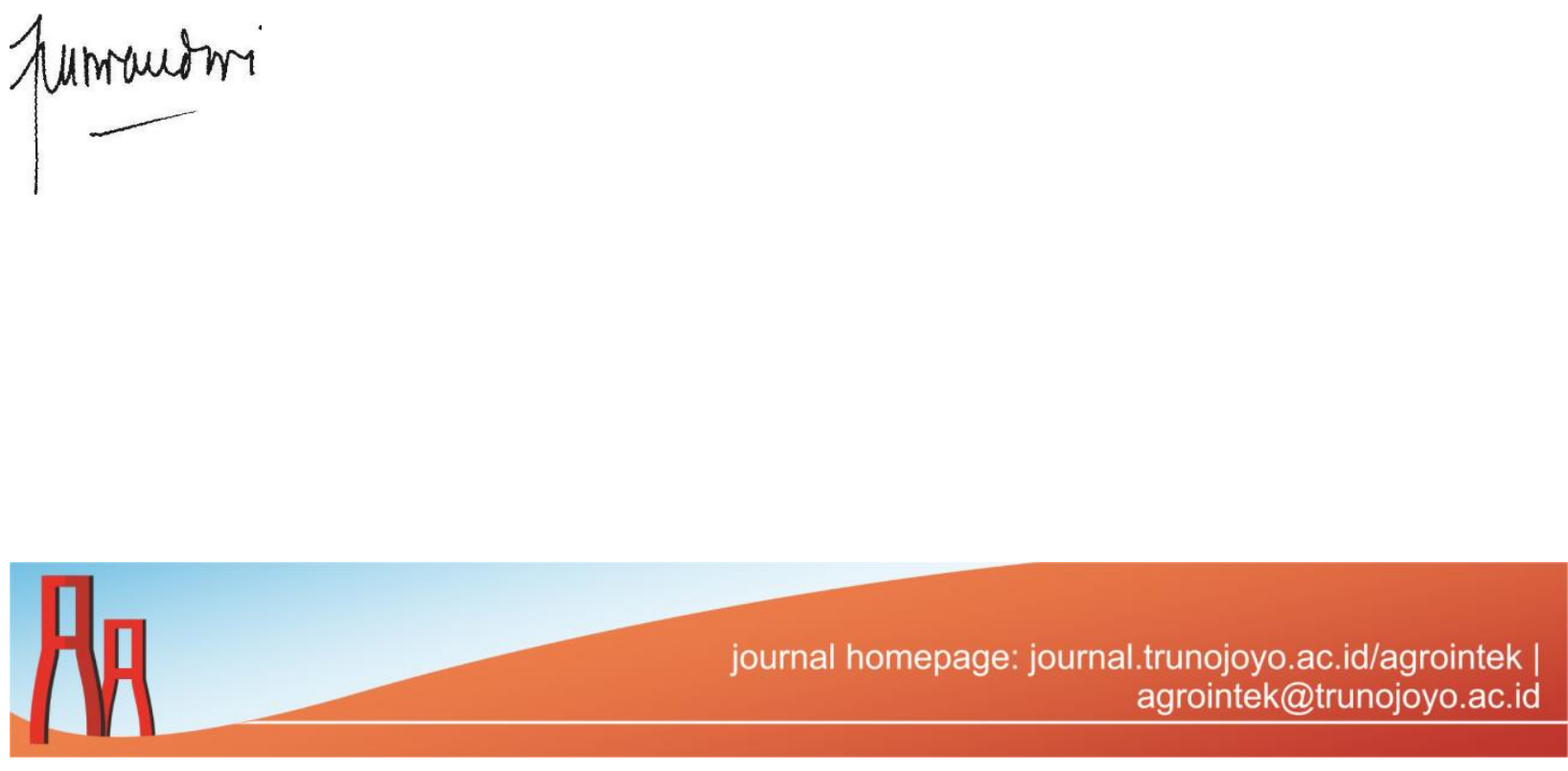


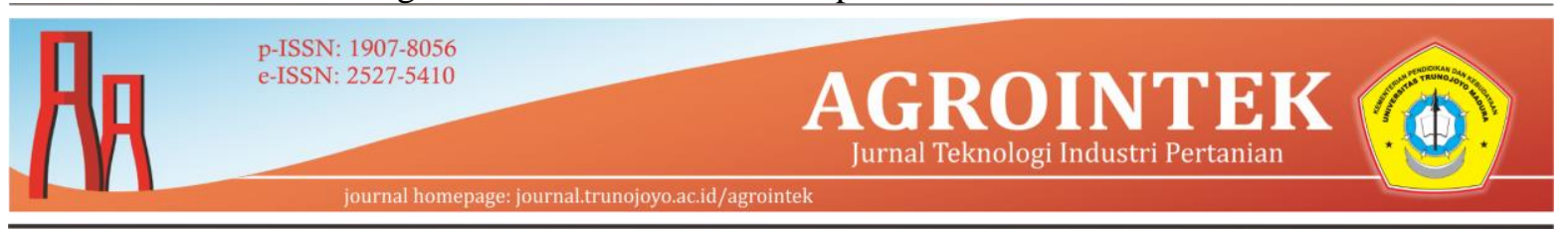

\title{
PRODUCTION OF ROBUSTA INSTANT COFFEE POWDER WITH VARIATION OF FILLERS
}

\author{
Miftahul Wahidatun Ni'mah, Umar Hafidz Asy'ari Hasbullah*, Endang Is Retnowati
}

Study Program of Food Technology, Universitas PGRI Semarang, Jawa Tengah, Indonesia

Article history
Received:
15 May 2021
Revised:
2 June 2021
Accepted:
27 July 2021
Keyword
Instant coffee powder;
Robusta; filler;
maltodextrin; dextrin

\begin{abstract}
Instant coffee powder is a downstream product of coffee processing. This research aimed to study the effect of fillers on the physical, chemical, and sensory properties of instant coffee powder. This study was used Robusta coffee which was roasted at medium to dark levels. The fillers used were maltodextrin and dextrin. The instant coffee powder was made by crystallization and drying techniques with a cabinet dryer. The results showed that the difference between the two fillers did not affect the physical properties of instant coffee powder, such as yield, $\mathrm{pH}$, solubility, brightness $\left(L^{*}\right)$, and yellowishness $\left(b^{*}\right)$. Meanwhile, the chemical properties of water content showed a significant difference between the two treatments. The sensory properties of the two treatments have a description of the color tends to be bright, slightly brown, the taste was quite bitter, slightly sweet, quite sour, the aftertaste was medium sour, the aftertaste was low in smoke, the aftertaste was quite detectable, the aroma of coffee was medium, slightly sweet, and slightly caramel-flavored. The instant coffee powder has the potential to be developed as a coffee flavoring preparation for food products.
\end{abstract}

(C) all right reserved

\footnotetext{
* Penulis korespondensi

Email : umarhafidzah@gmail.com

DOI 10.21107/agrointek.v15i3.10629
} 


\section{INTRODUCTION}

Coffee is one of the most consumed drinks in the world (Toci et al., 2013). Based on data from the International Coffee Organization (ICO), the level of world coffee consumption in 2015 reached 152.2 million per $60 \mathrm{~kg}$ of coffee and has increased an annual average of $2 \%$ since 2011. In the last four years, coffee consumption in Indonesia has continued to increase by $36 \%$ from 2010 to 2014, with total consumption of 1.03 $\mathrm{kg} / \mathrm{capita} /$ year in 2014 (AEKI, 2014). Types of coffee that are widely cultivated include Arabica coffee (Coffea arabica) and Robusta (Coffea canephora) (Vignoli et al., 2011). Indonesia is one of the largest producers and exporters of Robusta coffee in the world. It is because the climatic conditions are suitable for Robusta coffee cultivation. In addition, Robusta coffee has the advantage of being resistant to disease and has the strongest aroma and taste among other types of coffee (Nurhayati, 2018). Most of the coffee production in Indonesia is exported abroad, and the rest is marketed domestically.

Coffee is traded in various forms, i.e., green coffee beans, roasted coffee beans, ground coffee or powder coffee, extracted coffee, instant coffee, dipped coffee, and ready-to-drink coffee. Ground coffee is the result of grinding coffee beans that have been roasted and divided into coarse, medium, and fine (Shafira, 2018). Instant coffee powder drinks include coffee bean processed products that have the potential to be developed because they are popular with the community, do not leave pulp, and are easily soluble in water compared to ground coffee (Apriani et al., 2016). Making instant coffee powder requires a filler.

The addition of fillers aims to coat the flavor components, increase the total amount of solids, increase the volume, speed up the drying process, prevent material damage due to heat, and increase the solubility and organoleptic properties of instant coffee powder drinks (Putra \& Ekawati, 2013). The use of this type of filler is necessary to produce instant coffee powder drinks that are of good quality and are liked by the panelists.

Fillers that are often used for powdered beverage products are dextrins and maltodextrin. Dextrin is a polysaccharide compound that dissolves in water and can bind hydrophobic substances so that it is widely used as a food additive (Winarno, 2004). Meanwhile, maltodextrin has been used as a filler in powder products (Ramadhia et al., 2012).

Therefore, this study examines the effect of fillers on the physical, chemical, and organoleptic characteristics of instant drink powder from robusta coffee.

\section{METHOD}

\section{Materials}

The material used in this research was Robusta Gunung Kelir coffee (Shine Coffee Solo). Chemicals such as maltodextrin (Food Grade), dextrin (Food Grade), tween 80 (polysorbate), and aquadest.

\section{Equipment}

The tools used for the production of the samples were analytical scales (Shimadzu ATX224), blender, hand blender, filter, Teflon (Maxim), gas stove, stirrer, baking sheet, cabinet dryer, coffee roaster machine (SC-2.5 Kg), and 60 mesh sieve. While the tools used for the analysis were analytical scales (Shimadzu ATX224), aluminum plates, glassware, vortices, spatulas, vacuum pumps, $\mathrm{pH}$ meters (Horiba $\mathrm{pH} 130-\mathrm{K}$ ), stopwatches, forms, ovens (Memmert UF30), and desiccators.

\section{Roasting of Coffee Beans}

Roasting coffee beans was done at a medium to dark roast level. The roaster machine (SC$2.5 \mathrm{Kg}$ ) was set with an initial temperature of $180^{\circ} \mathrm{C}$. Roasting was carried out for 10 minutes. Roasted beans were cooled to room temperature, then ground and sieved 60 mesh. Coffee grounds were stored in a validated aluminum foil package until further processing.

\section{Extracting Robusta Coffee (Maharani, 2020 modified)}

Coffee grounds dissolved with distilled water at a temperature of $93^{\circ} \mathrm{C}$ with a ratio of $1: 5(\mathrm{w} / \mathrm{v})$. Next, stir for 4 minutes. And it filtered with a vacuum filter (Pyrex 500ml). The coffee extract was stored in a cooler until it was used for the following process.

\section{Making of Instant Coffee Powder (Simpatik, 2018 modified)}

Robusta coffee extract was added with $30 \%$ fillers (maltodextrin or dextrin) and $0.01 \%$ tween 80. The mixture was homogenized. Then boil it in Teflon until it boils, and dried in a cabinet dryer at $50^{\circ} \mathrm{C}$ for 24 hours. Grinding of the coffee instant and sieved in 60 mesh. The instant coffee powder 
was stored in aluminum foil packaging until analyzed.

\section{Rendement Analysis (AOAC, 1990).}

The rendement was calculated by comparing the weight of instant coffee powder produced with raw materials. The rendement was calculated in percentage units.

\section{pH Analysis (Septianingrum et al., 2019 modified)}

Several samples of instant coffee powder were dissolved in distilled water or distilled water with a ratio of $1: 10(\mathrm{w} / \mathrm{v})$. The $\mathrm{pH}$ measurements were carried out with a $\mathrm{pH}$ meter.

Solubility Analysis (Asri et al., 2018).

Whatman filter paper No. 42 was dried in an oven at $105{ }^{\circ} \mathrm{C}$ for 30 minutes, then weighed. A sample of $3.5 \mathrm{~g}$ of instant coffee powder was dissolved in $100 \mathrm{ml}$ of distilled water then filtered with Whatman No. filter paper. Forty-two on a Buchner funnel and vacuum pump was drawn. Furthermore, the filter paper containing the insoluble particles was heated at $105{ }^{\circ} \mathrm{C}$ for 3 hours, then cooled in a desiccator and weighed.

$$
\text { Solubility }=\frac{\text { initial weight }- \text { final weight }}{\text { initial weight }} \times 100 \%
$$

The final weight was the difference from the weight of the filter paper after filtering by weight before filtering.

\section{Color Analysis (Deman, 1999).}

Color analysis was using a Chromameter CR 300 (FRU, Japan). The samples were analyzed for $\mathrm{L}^{*}, \mathrm{a}^{*}$, and $\mathrm{b}^{*}$ values. The sample was compared with Robusta and Arabica powder. The $\mathrm{L}^{*}$ value indicates the change in brightness or lightness with a value range from 0 (black) to 100 (white). Value of $a^{*}$ represents red-green mixed chromatic color with $+\mathrm{a}^{*}$ value ranging from 0 to 100 for red, and $-\mathrm{a}^{*}$ values ranging from 0 to -80 for green. Whereas the value of $b^{*}$ represents the chromatic color of a blue-yellow mixture with a value of + $b^{*}$ from 0 to +70 for blue and a value of $-b^{*}$ from 0 to -70 for yellow.

\section{Moisture Content Analysis (AOAC, 2005)}

A total of $2 \mathrm{~g}$ of sample was weighed and dried in an oven at $105^{\circ} \mathrm{C}$ for 12 hours. Then the sample was placed in a desiccator to room temperature. The plate containing the sample was weighed until a constant weight was obtained.

$$
\text { Moisture content }(\%)=\frac{(\mathrm{W}-(\mathrm{W} 1-\mathrm{W} 2))}{\mathrm{W}} \mathrm{x} 100 \%
$$

Note: W (gram of initial sample); W1 (gram of final sample + empty cup); W2 (gram cup).

\section{Sensory Analysis}

The sensory test was carried out by the descriptive method. The test was carried out using ten trained panelists. The testing phase begins with an FGD of panelists recruited to detect the quality attributes that were expected to appear in the sample. Furthermore, the panelists were introduced to the attributes to be measured. Panelists were trained to detect the intensity and standard of each attribute to be tested. After the researcher recognizes and practices the intensity of the tested attribute standards, the perception of attributes and intensity were equalized before testing the sample. Sample testing was carried out on the instant coffee powder.

The parameters tested include sweet taste, bitter taste, sour taste, coffee aroma, sweet aroma, caramel aroma, smoke aftertaste, bitter aftertaste, sour aftertaste, brown color, and color intensity.

\section{Data Analysis}

Data were analyzed using the T-test on the analysis of yield, $\mathrm{pH}$, freshness, and moisture content. Meanwhile, the diversity test (One way ANOVA) in color analysis. If there was a difference, continue the DMRT test with a confidence level of 95\%. Data analysis was performed using the SPSS 24.0 program.

\section{RESULTS AND DISCUSSION \\ Rendement}

The rendement was one of the factors related to the economic value of a product. The greater the rendement, the better the results of a processing process (Setyaningrum, 2017). Rendement was the percentage of product produced after processing. The rendement of instant coffee powder was presented in Figure 1.

The rendement of instant coffee powder using dextrin and maltodextrin filler was $24.61 \%$ and $23.37 \%$, respectively (Figure 1). The difference in filler did not cause a significant difference in the rendement of instant coffee powder. Presumably, the concentration of maltodextrin and dextrin added to the formula was the same amount (30\%). 


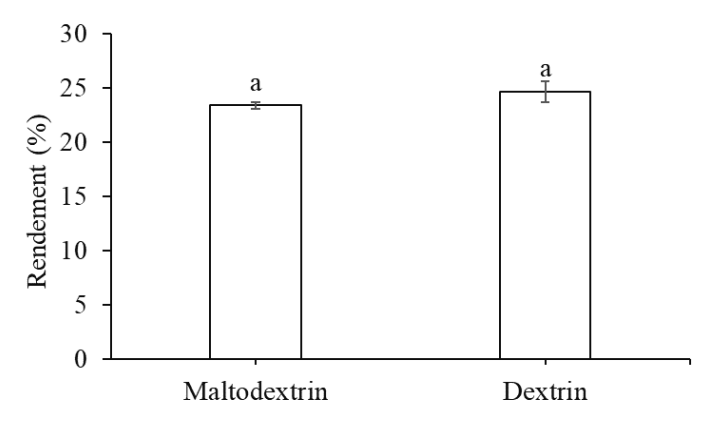

Figure 1 Instant Coffee Powder Rendement. Data were presented with standard deviation lines. Different letter notation indicates significantly different $(\mathrm{P}$ $<0.05)$.

Besides that, it can also be caused by the density of the two fillers, which were almost the same. Maltodextrin has a density of $504.5 \mathrm{gr} / \mathrm{mol}$, while the density of dextrin was $504.4 \mathrm{gr} / \mathrm{mol}$ (Pubchem, 2021).

The use of dextrin and maltodextrin as filler was also carried out in the manufacture of red guava fruit pollen (Suryanto, 2018), noni fruit powder drink (Kaljannah et al., 2018), and instant pollen, a mixture of tamarillo and purple passion fruit juice (Setyaningrum, 2017). The addition of dextrin and maltodextrin has increased the yield of the final powder product. Vareltzis et al. (2020) reported that instant coffee made by spray drying method without filler could produce up to $54.5 \%$. pH

The value of the degree of acidity $(\mathrm{pH})$ was closely related to the acidity of a product (Setyaningrum, 2017). The $\mathrm{pH}$ value of the instant coffee powder was shown in Figure 2.

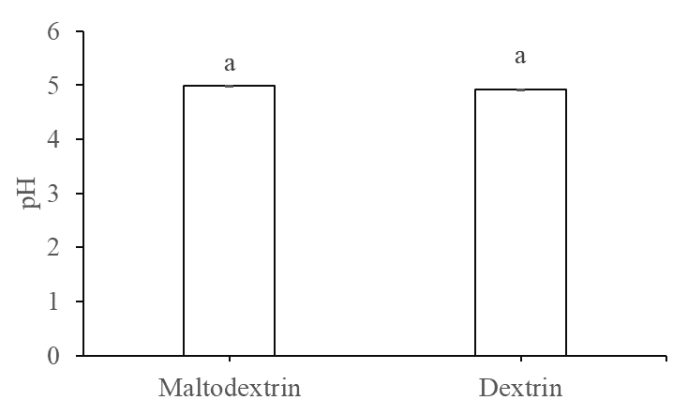

Figure 2 The $\mathrm{pH}$ of Instant Coffee Powder. Data were presented with standard deviation lines. Different letter notation indicates significantly different $(\mathrm{P}$ $<0.05)$.

The difference in fillers in the manufacture of instant coffee powder did not significantly affect the difference in $\mathrm{pH}(\mathrm{P}>0.05)$ (Figure 2). The $\mathrm{pH}$ value of instant coffee powder with filler maltodextrin and dextrin was 4.99 and 4.92, respectively. However, the $\mathrm{pH}$ value of instant coffee powder with maltodextrin filler has a slightly higher value than dextrin. This was due to the difference in the $\mathrm{pH}$ of the two fillers. Maltodextrin has a higher $\mathrm{pH}$ value than dextrin. Based on measurements of the two fillers, maltodextrin has a $\mathrm{pH}$ of 4.1 , while dextrin has a $\mathrm{pH}$ of 3 .

Maltodextrin can neutralize acids. The addition of maltodextrin in making instant drinks can reduce the sour taste of drinks (Retnaningsih \& Tari, 2014). Maltodextrin comes from oligosaccharides, which were compounds containing a lot of hydroxyls $(\mathrm{OH})$ groups to neutralize the acidic properties of the raw material. In contrast, filler dextrin causes the $\mathrm{pH}$ value to be lower due to the presence of residual acid due to the acid or enzyme hydrolysis process when making dextrin (Wiyono, 2017).

\section{Solubility}

Solubility was one of the critical parameters of instant drink powder. The higher the solubility, the larger the dispersed particles and the fewer dregs involved in the brewing (Matanari et al., 2020). The solubility of instant coffee powder was presented in Figure 3.

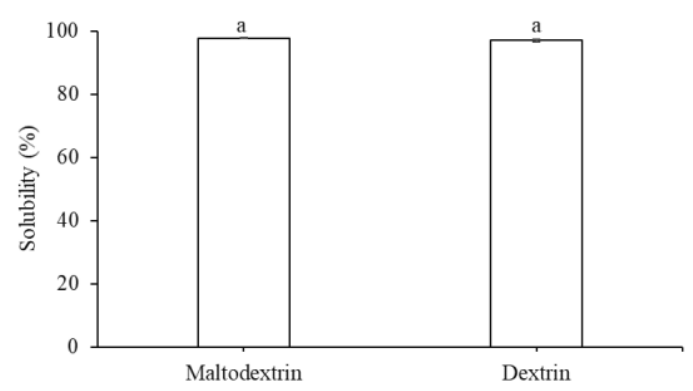

Figure 3 Instant Coffee Powder Solubility. Data were presented with standard deviation lines. Different letter notations indicated significantly different $(\mathrm{P}$ $<0.05)$.

The difference in fillers used in the manufacture of instant coffee powder has no significant effect on the solubility of the powder. This was presumably due to the similarity in the water solubility of the two fillers. The solubility of maltodextrin and dextrin was $0.1 \mathrm{~g} / \mathrm{ml}$ (ChemicalBook, 2021).

However, the percent solubility of powder with maltodextrin filler was slightly higher than dextrin filler, $97.7 \%$, and $96.9 \%$, respectively. This was possible because maltodextrin has properties that can bind hydrophobic substances. 
In addition, maltodextrin was an oligosaccharide that was very soluble in water so that it can form an evenly dispersed solution system (Retnaningsih \& Tari, 2014). The difference in the value of DE (Dextrose Equivalent) may also have a slight effect. Maltodextrin has a DE value of 3-20, while dextrin is 3-5 (Wulansari et al., 2012). Mursalin et al. (2019) reported that the solubility of instant Liberica coffee made by crystallizing granulated sugar $(35 \%)$ was $97.95 \%$.

\section{CIELab Colors}

The color of the instant coffee powder was indicated by the values of $L^{*}, a^{*}$, and $b^{*}$. The appearance of instant coffee powder can be seen in Figure 4.
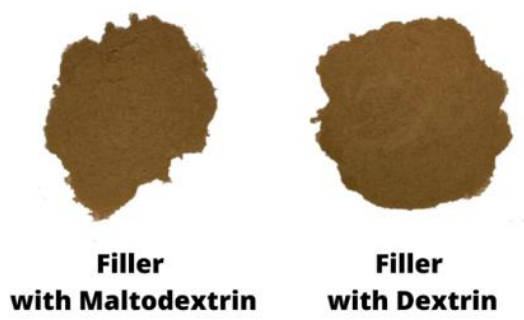

Figure 4 Instant coffee powder with different filler

\section{$L *$ value}

The $L^{*}$ value indicates the color brightness level in 0 (black) -100 (white). The brighter the sample color, the higher the $L^{*}$ value (Yam \& Papadakis, 2004). The $L^{*}$ values of instant coffee powder were shown in Figure 5.

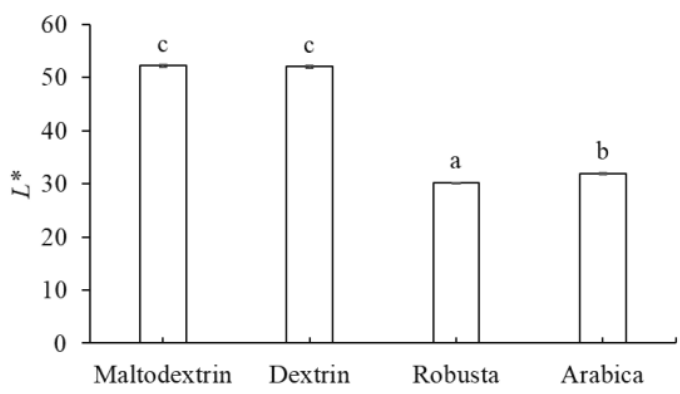

Figure 5 The $L^{*}$ Value of Instant Coffee Powder. Data were presented with standard deviation lines. Different letter notation indicates significantly different $(\mathrm{P}$ $<0.05)$.

The filler difference did not significantly affect the brightness $\left(L^{*}\right)$ of the instant coffee powder. However, the brightness of instant coffee powder was significantly different from Robusta and Arabica coffee powder. The brightness $\left(L^{*}\right)$ of instant coffee powder with filler maltodextrin and dextrin was 52.19 and 52.04, respectively.
Meanwhile, the control brightness in Robusta coffee powder and Arabica were 30.15 and 31.88, respectively.

The difference in brightness between instant coffee powder and Robusta and Arabica coffee powder control was possible because the filler has a white color (Putri et al., 2019) and will cause the brown color of the coffee extract to fade. The addition of more maltodextrin in the pumpkin instant powder formulation makes the color of the powder drink brighter (Ningtias et al., 2019). The addition of dextrin as a filler for ginger effervescent powder causes the brightness of the product to increase (Wiyono, 2017).

\section{$a^{*}$ Value}

The value of $a *$ indicates the chromatic color of the red-green mixture. Positive values from 0 to +100 indicate red. Meanwhile, negative values from 0 to -80 indicate a green color (Yam \& Papadakis, 2004). The $a^{*}$ values of instant coffee powder were shown in Figure 6.

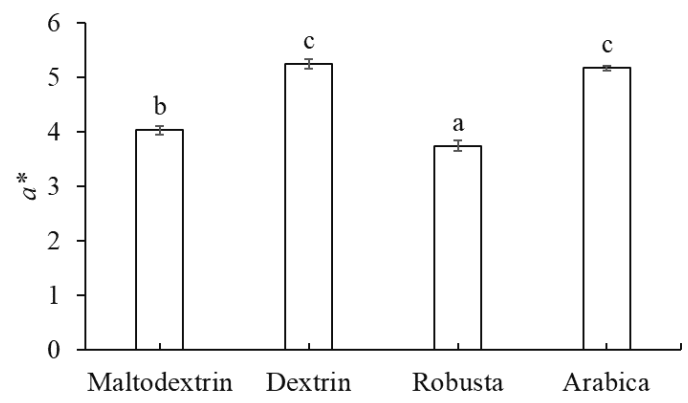

Figure 6 The value of $a^{*}$ Instant Coffee Powder. Data were presented with standard deviation lines. Different letter notation indicates significantly different $(\mathrm{P}$ $<0.05)$

The difference in fillers in the manufacture of instant coffee powder causes a significant difference in the reddish $\left(a^{*}\right)$ color of the powder. The reddish color of instant coffee powder was significantly different from Robusta coffee powder. The $a^{*}$ value of instant coffee powder with filler dextrin was greater than dextrin, 5.24 and 4.03 , respectively. This was possible because during heating to high temperatures, the sugar groups on the dextrin experience browning (Rizal $\&$ Putri, 2014). Meanwhile, maltodextrin was more challenging to cause browning than dextrin (Srihari et al., 2010). In addition, maltodextrin has a whiter color than dextrin, reducing the reddish color of instant coffee powder (Yuliawaty \& Susanto, 2015). 


\section{$b^{*}$ Value}

The $b^{*}$ value indicates the chromatic color of the blue-yellow mixture. Positive values from 0 to +70 indicate yellow. Meanwhile, negative values from 0 to -80 indicate blue color (Yam \& Papadakis, 2004). The value of $b^{*}$ instant coffee powder was shown in Figure 7.

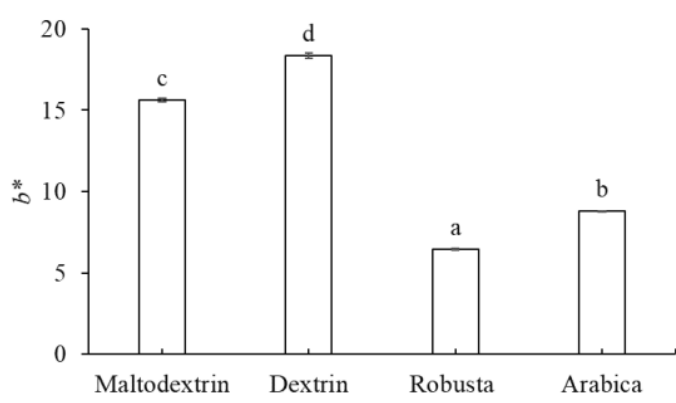

Figure 7 The $b^{*}$ Value Instant Coffee Powder. Data were presented with standard deviation lines. Different

letter notation indicates significantly different $(\mathrm{P}$ $<0.05)$

The difference in fillers in the manufacture of instant coffee powder causes a significant difference in the powder's yellowish color ( $\left.b^{*}\right)$. The yellowish color of the powder was significantly different from the control of Robusta and Arabica coffee powder. The $b^{*}$ value of instant coffee powder with dextrin filler was greater than maltodextrin filler, 18.35 and 15.61, respectively. Mean while, the $b^{*}$ control values for Robusta and Arabica coffee powder were 6.47 and 8.78, respectively.

The yellowish color of instant coffee powder with filler dextrin compared to maltodextrin was possible because dextrin color tends to be more yellow than maltodextrin (Saputra et al., 2016). The addition of more maltodextrin in the manufacture of anthocyanin powders from red cabbage and Telang flower causes the $b^{*}$ value of the powder to be lower (Putri et al., 2019). The addition of dextrin in the Curcuma effervescent powder formulation slightly increased the yellowish color of the powder (Wiyono, 2017).

\section{Moisture content}

The moisture content indicates the amount of free water present in the material (Retnaningsih \& Tari, 2014). The moisture content determined the quality of the final powder product. The instant coffee powder moisture content was shown in Figure 8.

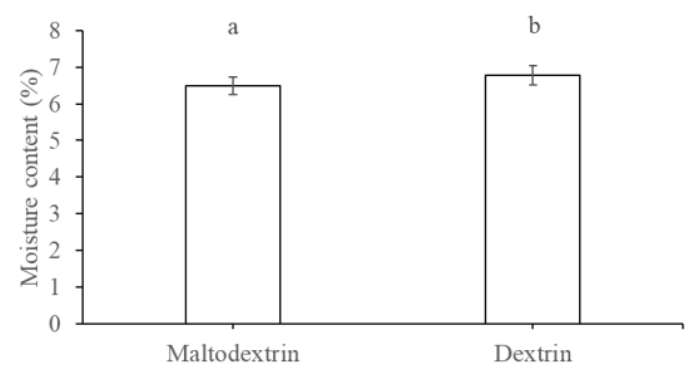

Figure 8 Moisture Content of Instant Coffee Powder. Data were presented with standard deviation lines.

Different letter notation indicates significantly different $(\mathrm{P}<0.05)$.

The difference in fillers in the manufacture of instant coffee powder caused a significant difference in moisture content. The moisture content of powder with dextrin filler was greater than maltodextrin, $6.9 \%$ and $6.5 \%$, respectively.

This was possible because maltodextrin has a more branched molecular structure than dextrin. Maltodextrin can reduce the binding capacity and interaction of the mixture with water so that it will be more easily evaporated during the heating process (Pratiwi \& Suharto, 2015). It was also possible because dextrin was composed of glucose units that can bind water (Saputra et al., 2016). Dextrin was thought to cause the reabsorption value of instant coffee powder to increase so that the water content increases. The addition of dextrin in the effervescent ginger powder caused the hydroxyl group contained in the powder to increase so that the reabsorption value was high. Large amounts of hydroxyl groups can increase the ability to bind water, causing high water content (Wiyono, 2017).

\section{Sensory Properties}

Sensory testing was done by descriptive test to describe the sensory profile of instant coffee powder. This test was used trained panelists to assess product characteristics, food quality, and shelf life (Rahmawati \& Fibrianto, 2018). A description of the sensory profile of the instant coffee powder was presented in Figure 9. 


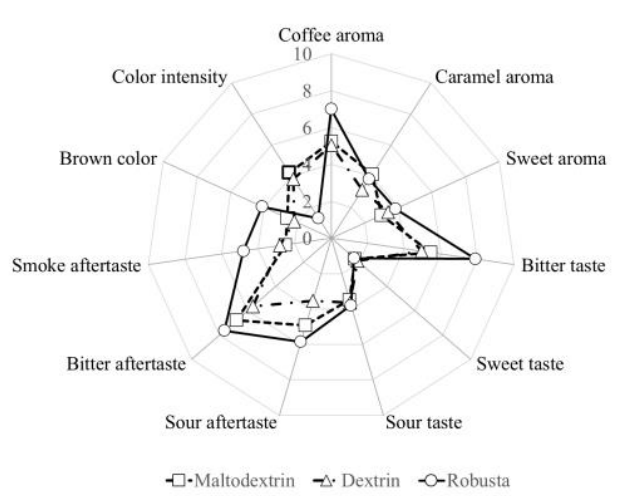

Figure 9 Sensory Profile of Instant Coffee Powder.

\section{Coffee aroma}

The aroma of coffee was the first aroma detected by the panelists. Researchers described the aroma of instant coffee powder made with maltodextrin and dextrin filters as having a moderate coffee aroma (5.1-5.3). Meanwhile, Robusta coffee powder control has a strong coffee aroma (7). The use of these two fillers can prevent the loss of coffee aroma in the instant coffee powder. The heating process in high temperatures during instant coffee processing was possible to cause a decrease in coffee aroma from coffee extracts. Maltodextrin and dextrin can trap the volatile compounds in the aroma of coffee during processing so that they will not be lost after becoming a powder (Tazar et al., 2017).

The distinctive aroma of coffee was caused by volatile compounds such as caffeol and other coffee aroma-forming compounds (Lokaria \& Susanti, 2018; Baggenstoss et al., 2010). Generally, volatile compounds that affect the aroma of coffee come from aldehyde, ketone, alcohol, furfural, pyrazine, and other groups (Ramanaviciene et al., 2003).

\section{Caramel aroma}

Researchers described instant coffee powder made with dextrin and maltodextrin filler as having a weak caramel aroma, although it has a slightly higher score than Robusta coffee powder. This indicates that the use of dextrin and maltodextrin as fillers in making instant coffee powder did not increase the caramel aroma drastically. Maltodextrin and dextrin do not have a characteristic aroma (Fajarwati, 2017). During high-temperature processing, dextrin and maltodextrins cause less caramel aroma due to the caramelization reaction. Caramelization occurs in sugar that was heated at high temperatures so that it will be dehydration and condensation, which results in brown compounds and caramel-flavored volatile compounds (Winarno, 2004).

\section{Sweet Aroma}

Panelists described instant coffee powder made with dextrin and maltodextrin filler as having a weak sweet aroma which was equivalent to Robusta coffee powder control.

The sweet aroma of instant coffee powder can arise due to the presence of furaneol compounds in coffee. Robusta roasted coffee contains a lot of furaneol compounds (2,5dimethyl-4-hydroxy- (2H)-furan-3-one) which have a description of sweet odors like caramel and a flavor like burnt sugar with quite fruity sensations. (Ardianti, 2017). In addition, the pyrazine compound also contributes to the sweetbitter aroma (Wilujeng \& Wikandari, 2013).

\section{Bitter taste}

Panelists described instant coffee powder made with filler maltodextrin and dextrin as having a moderately bitter taste. Meanwhile, Robusta coffee powder control has a strong bitter taste.

Decrease in the bitterness of instant coffee powder processed into instant coffee powder due to the addition of ingredients such as fillers. The maltodextrin and dextrin used as fillers have no taste (ChemicalBook, 2021).

The bitter taste was caused by the presence of mineral content along with the breakdown of crude fiber, chlorogenic acid, caffeine, tannins, and several other organic and inorganic compounds in coffee (Lokaria \& Susanti, 2018). In addition, the bitter taste can be caused by the temperature during roasting of chlorogenic acid, which will produce caffeine and phenolic substances, which contribute to the bitter taste in brewing coffee (Setyani et al., 2018).

\section{Sweet taste}

Panelists described instant coffee powder as having a sweet taste that was very weak and almost tasteless. Panelists also assessed the same thing in the Robusta coffee powder control.

The use of maltodextrin and dextrin did not increase the sweetness of the instant coffee powder because these two fillers did not have a sweet taste (ChemicalBook, 2021; Indriani \& Sulandari, 2013). The use of maltodextrin in the manufacture of Kerandang juice powder did not 
increase the sweetness of the powder produced (Djaafar et al., 2018).

\section{Sour taste}

Panelists described instant coffee powder as having a weak sour taste. Panelists described the same thing in the Robusta coffee powder control. The difference in fillers in the manufacture of instant coffee powder did not cause a change in the sour taste of the powder. The sour taste was caused by the presence of organic acids in coffee (Fauzi et al., 2016).

\section{Sour aftertaste}

The aftertaste was a taste that was left longer than usual after consuming food (Sativa et al., 2014). Researchers described instant coffee powder with maltodextrin filler and Robusta coffee powder control as having a moderate acid aftertaste. Meanwhile, instant coffee powder with dextrin filler was described as having a weak aftertaste. The acid aftertaste was caused by the presence of organic acids in coffee (Fauzi et al., 2016).

\section{Bitter aftertaste}

Panelists described instant coffee powder as having a slightly bitter aftertaste. Meanwhile, the control of Robusta coffee powder was described by the panelists as having a quite bitter aftertaste. Bitter aftertaste comes from the content of caffeine, tannin, and phenol compounds derived from coffee (Sanz et al., 2002).

\section{Smoke Aftertaste}

Panelists described instant coffee grounds as having a very weak smoky aftertaste. Meanwhile, the control of Robusta coffee powder was described by the panelists as having a reasonably weak smoke aftertaste. The smoke aftertaste was caused by the presence of phenol group compounds in coffee. This compound appears during the roasting process of coffee beans (Setyani et al., 2018).

\section{Brown color}

Panelists described the instant coffee powder as having a light brown color. Meanwhile, Robusta coffee powder control was described as brown. This was consistent with the results of the CIE Lab test, which showed that the $L^{*}$ value of instant coffee powder was lower, and the values of $a^{*}$ and $b^{*}$ were higher than Robusta coffee powder. The addition of fillers maltodextrin and dextrin increases the brightness and reduces the original color of the product (Kaljannah et al., 2018; Putri et al., 2019).

The brown color of the instant coffee powder was due to the brown color of the coffee extract. The brown color of coffee occurs due to the Maillard reaction and caramelization during the roasting of the coffee beans (Setyani et al., 2018).

\section{Color Intensity}

Panelists described instant coffee powder as having a slightly dim color intensity. Meanwhile, Arabica coffee powder control was described as having a very faint color intensity. This corresponds to the $L^{*}$ value data (Figure 5). The brighter the color intensity of the instant coffee powder compared to the Robusta coffee powder control was possible because the colors of the maltodextrin and dextrin used as filler tend to be white so that the final color of the product will fade (Kaljannah et al., 2018).

\section{CONCLUSION}

The difference in fillers did not give a significant difference to physical properties such as yield, $\mathrm{pH}$, solubility, brightness $\left(L^{*}\right)$, and yellowish $\left(b^{*}\right)$ values. Meanwhile, the chemical properties in the form of water content showed significant differences between the two types of filler treatments. The sensory properties of the two treatments have a description of the color that tends to be bright, slightly brown. The taste was quite bitter, slightly sweet, quite sour. The aftertaste was medium sour, the aftertaste was low in smoke, the aftertaste was quite detectable, the aroma of coffee was medium, slightly sweet, and slightly caramel-flavored.

\section{ACKNOWLEDGMENT}

This research was funded by LPPM Universitas PGRI Semarang.

\section{REFERENCES}

AEKI. (2014). Industri Kopi Indonesia. Accessed on 10 April 2021. <http://Www.AekiAice.Org/Page/Industrikopi/Id >

AOAC. (1990). AOAC: Official Methods of Analysis (Volume 1). Association of Official Analytical Chemistry.

AOAC, A. of O. A. C. (2005). Official Method of Analysis (Issue February). Association of Official Analytical Chemistry.

Apriani, F. U., Efendi, R., \& Rossi, E. (2016). Pembuatan Minuman Serbuk Kopi 
(Arabica) Instan dengan Penambahan Ekstrak Kulit Manggis. Jurnal Online Mahasiswa Faperta, 3(2), 1-11.

Ardianti, A. D. (2017). Pengaruh Air Alkali dan Air Teroksigenasi sebagai Peyeduh terhadap Persepsi Multi Sensoris Kopi. Skripsi. Unversitas Brawijaya.

Asri, W., Nur, A. S., \& Sarifah, N. (2018). Pengaruh Penambahan Maltodekstrin terhadap Karakteristik Fisikokimia Bubuk Tomat Hasil Pengeringan Pembusaan (Foam Mat Drying). Agrin, 2(1), 22-38.

Baggenstoss, J., Poisson, L., Glabasnia, A., Moser, M., \& Rytz, A. (2010). Advanced Analytical-Sensory Correlation - Towards a Better Understanding of Coffee Flavor Perception. ASIC 23rd International Conference on Coffee Science, October, 125-132.

ChemicalBook. (2021). Productindex_en. Accessed on 21 April 2021. <https://www.chemicalbook.com>.

Deman, J. M. (1999). Principles of Food Chemistry Third Edition. Aspen Publishers, Inc.

Djaafar, T. F., Santoso, U., \& Ariestyanta, A. (2018). Pengaruh Penambahan Maltodekstrin dan Suhu Inlet Spray Dryer terhadap Karakteristik Fisiko-Kimia Bubuk Sari Kerandang (Canavalia virosa). Agritech, 37(3), 334. https://doi.org/10.22146/agritech.10446

Fajarwati, D. S. (2017). The Effect of Sucrose and Matodextrins Combination on Physicochemical and OrganolepticParameters of Soybean Sweetened Condensed Milk. Jurnal Pangan dan Agroindustri, 5(3), 72-82.

Fauzi, M., Giyarto, \& Wulandari, S. (2016). Karakteristik Citarasa Dan Komponen Flavor Kopi Luwak Robusta In Vitro Berdasarkan Dosis Ragi Kopi Luwak dan Lama Fermentasi. Semnas Hasil Penelitian Dan Pengabdian Masyarakat, 51-56.

Indriani, S., \& Sulandari, L. (2013). Pengaruh Jumlah Dekstrin dan Lama Pengeringan Terhadap Sifat Organoleptik dan Sifat Mikrobiologi Yogurt Bubuk. Boga, 2(1), 80-89.

Kaljannah, A. R., Indriyani, \& Ulyarti. (2018). Pengaruh Konsentrasi Maltodekstrin terhadap Sifat Fisik, Kimia, dan
Organoleptik Minuman Serbuk Buah Mengkudu (Morinda citrifolia L). Prosiding Semnas UNEJ, 297-308.

Lokaria, E., \& Susanti, I. (2018). Uji Organoleptik Kopi Biji Salak dengan Varian Waktu Penyangraian. Jurnal Pendidikan Biologi Dan Sains, 1(1), 34-42. https://doi.org/10.31539/bioedusains.v1i1. 262

Maharani, Z. (2020). Pengaruh Frekuensi Penyeduhan dan Tingkat Penyangraian Terhadap Aktivitas Antioksidan dan Profil Sensoris Kopi Arabika dan Robusta. Skripsi. Universitas PGRI Semarang.

Matanari, F., Mursalin, \& Gusriani, I. (2020). Pengaruh Penambahan Konsentrasi Maltodeksrin Terhadap Mutu Kopi Instan dari Bubuk Kopi Robusta (Coffea canephora) dengan Menggunakan Vakum Dryer. Semirata BKS PTN Wilayah Barat, 922-941.

Mursalin, M., Nizori, A., \& Rahmayani, I. (2019). Sifat Fisiko-Kimia Kopi Seduh Instan Liberika Tungkal Jambi yang Diproduksi Dengan Metode Kokristalisasi. Jurnal Ilmiah Ilmu Terapan Universitas Jambi (JIITUJ), 3(1), 71-77. https://doi.org/10.22437/jiituj.v3i1.7344

Nadya, A. S. (2018). Pengembangan Produk Minuman Kopi Siap Minum (Ready-toDrink) Berdasarkan Prefelensi Konsumen di Kota Bogor. Skripsi. Institut Pertanian Bogor.

Ningtias, D. F. C., Suyanto, A., \& Nurhidajah. (2019). Betakaroten, Antioksidan dan Mutu Hedonik Minuman Instan Labu Kuning (Cucurbita moschata Dutch) Berdasarkan Konsentrasi Maltodekstrin. Jurnal Pangan Dan Gizi, 7(2), 1-224. https://doi.org/10.1017/CBO97811074153 24.004

Nurhayati, N. (2018). Karakteristik Sensori Kopi Celup dan Kopi Instan Varietas Robusta dan Arabika. Jurnal Ilmiah Inovasi, 17(2), $80-85$. https://doi.org/10.25047/jii.v17i2.547

Pratiwi, A. D., \& Suharto, I. (2015). Pengaruh Temperatur dan Tebal Lapisan Susu Kedelai pada Tray dalam Pengeringan Busa terhadap Kualitas Susu Kedelai Bubuk. Prosiding Seminar Nasional Teknik Kimia "Kejuangan," 1-6. 
Pubchem. (2021). Compound. Accessed on 02 Mei 2021. <https://www.https://pubchem.ncbi.com>.

Putra, S. D. R., \& Ekawati, L. . (2013). Kualitas Minuman Serbuk Instan Kulit Buah Manggis (Garcinia mangostana Linn.) dengan Variasi Maltodekstrin dan Suhu Pemanasan. Jurnal Biologi, 1(1), 1-15.

Putri, N. I., Chance, M. J., Rahardjo, P. A. C., \& Ananingsih, V. K. (2019). Pengarih Jenis dan Konsentrasi Enkapsulan dalam Proses Pembuatan Serbuk Antosianin dari Kubis Merah dan Bunga Telang. Jurnal Teknologi Pangan Dan Gizi, 18(1), 1-9.

Rahmawati, M. A., \& Fibrianto, K. (2018). Karakteristik sensorik kopi Robusta Dampit: Kajian Pustaka Sensory. Jurnal Pangan Dan Agroindustri, 6(1), 75-79.

Ramadhia, M., Kumalaningsih, S., \& Santoso, I. (2012). Pembuatan Tepung Lidah Buaya (Aloe vera L.) dengan Metode Foam-Mat Drying. Jurnal Teknologi Pertanian, 13(2), 125-137.

Ramanaviciene, A., Mostovojus, V., Bachmotova, I., \& Ramanavicius, A. (2003). Antibacterial Effect of Caffeine on Escherichia coli and Pseudomonas fluorescens. Journal Acta Medica Lituanica, 10(4), 185-188.

Retnaningsih, N., \& Tari, A. I. N. (2014). Analisis Minuman Instan Secang: Tinjauan Proporsi Putih Telur, Maltodekstrin, dan Kelayakan Usaha. Agrin, 18(2), 129-147.

Rizal, D., \& Putri, W. D. R. (2014). Pembuatan Serbuk Effervescent Miana ( Coleus ( L ) benth ): Kajian Konsnetrasi Dekstrin Dan Asam Sitrat Terhadap Karakteristik Serbuk Effervescent. Jurnal Pangan Dan Agroindustri, 2(4), 210-219.

Sanz, C., Maeztu, L., Jose Zapelena, M., Bello, J., \& Cid, C. (2002). Profiles of Volatile Compounds and Sensory Analysis of Three Blends of Coffee: Influence of Different Proportions of Arabica and Robusta and Influence of Roasting Coffee with Sugar. Journal of the Science of Food and Agriculture, 82(8), 840-847. https://doi.org/10.1002/jsfa.1110

Saputra, I. W. A., P Pratiwi, I. A. R., \& Gunadnya, I. B. P. (2016). Pengaruh Konsentrasi Dekstrin dan Tween 80 (Polyoxyethylene Sorbitan Monooleat) pada Proses Pengeringan Gel Daun Lidah Buaya (Aloe barbadensis Miller) dengan Cabinet Dryer.
BETA (Biosistem Dan Teknik Pertanian), 4(2), 8-16.

Sativa, O., Yuwana, \& Bonodikun. (2014). Karakterisik Fisik Buah Kopi, Kopi Beras dan Hasil Olahan Kopi Rakyat di Desa Sindang Jati, Kabupaten Rejang Lebong. Jurnal Agroindustri, 4(2), 65-77.

Septianingrum, N. M. A. N., Hapsari, W. S., \& Amin, M. K. (2019). Formulasi dan Uji Sediaan Serbuk Effervescent Ekstrak Okra ( Abelmoschus Esculentus ) sebagai Nutridink pada Penderita Diabetes. Media Farmasi, 16, 11-20.

Setyani, S., Subeki, S., \& Grace, H. A. (2018). Evaluasi Nilai Cacat dan Cita Rasa Kopi Robusta (Coffea canephora L.) yang Diproduksi IKM Kopi di Kabupaten Tanggamus. Jurnal Teknologi \& Industri Hasil Pertanian, 23(2), 103. https://doi.org/10.23960/jtihp.v23i2.103114

Setyaningrum, D. Y. (2017). Optimasi Formula Minuman Fungsional Serbuk Instan Campuran Sari Buah Terong Belanda (Cyphomandra betaceae) dan Markisa Ungu (Passiflora edulis) dengan Metode Pengeringan Busa (Foam Mat Drying). Institut Pertanian Bogor.

Simpatik, S. R. (2018). Pengaruh Konsentrasi Asam Sitrat Terhadap Effervescent Beras Kencur. Skripsi. UPGRIS.

Srihari, E., Lingganingrum, S. F., Hervita, R., \& Wijaya, H. (2010). Pengaruh Penambahan Maltodekstrin pada Pembuatan Santan Kelapa Bubuk. Seminar Rekayasa Kimia Dan Proses, 1-7.

Suryanto, R. (2018). Pengaruh Penambahan Dekstrin dan Tween 80 Terhadap Sifak Fisik, Kimia dan Organoleptik Bubuk Sari Buah Jambu Biji Merah (Psidium Guajava L.) yang Dibuat dengan Metod Foam-Mat Drying. Jurnal Ilmu Sosial Dan Pendidikan, 2(3), 71-79.

Tazar, N., Violalita, F., Harmi, M., \& Fahmy, K. (2017). Pengaruh Perbedaan Jenis dan Konsentrasi Bahan Pengisi Terhadap Karakteristik Pewarna Buah Senduduk. Journal, Geological, 13(2), 224-234.

Toci, A. T., Neto, V. J. M. F., Torres, A. G., \& Farah, A. (2013). Changes in Triacylglycerols and Free Fatty Acids Composition during Storage of Roasted Coffee. LWT - Food Science and 
Technology, 50(2), 581-590. https://doi.org/10.1016/j.lwt.2012.08.007

Vareltzis, P., Gargali, I., Kiroglou, S., \& Zeleskidou, M. (2020). Production of instant coffee from cold brewed coffee; process characteristics and optimization. Food Science And Applied Biotechnology, 3(1), 39-46. doi:10.30721/fsab2020.v3.i1.92

Vignoli, J. A., Bassoli, D. G., \& Benassi, M. T. (2011). Antioxidant Activity , Polyphenols , Caffeine and Melanoidins in Soluble Coffee: The Influence of Processing Conditions and Raw Material. Food Chemistry, 124(3), 863-868. https://doi.org/10.1016/j.foodchem.2010.0 7.008

Wilujeng, A. A. T., \& Wikandari, P. R. (2013). Pengaruh Lama Fermentasi Kopi Arabika (Coffea arabica) dengan Bakteri Asam Laktat Lactobacillus plantarum b1765 terhadap Mutu Produk. UNESA Journal of Chemistry, 2(3), 1-10.

Winarno, F. G. (2004). Kimia Pangan dan Gizi. PT. Gramedia Pustaka Utama.

Wiyono, R. (2017). Studi Pembuatan Serbuk Effervescent Temulawak (Curcuma xanthorrhiza roxb) Kajian Suhu Pengering, Konsentrasi Dekstrin, dan Na-Bikarbonat. Jurnal Teknologi Pangan, 1(1), 1-31. https://doi.org/https://doi.org/10.35891/tp.v $1 \mathrm{i} 1.477$

Wulansari, A., Prasetyo, D. B., Lejaringtyas, M., Hidayat, A., \& Anggarini, S. (2012). Aplikasi dan Analisis Kelayakan Pewarna Bubuk Merah Alami Berantioksidan dari Ekstrak Biji Buah Pinang (Areca catechu) sebagai Bahan Pengganti Pewarna Sintetik pada Produk Pangan. Jurnal Industria, 1(1), $1-9$.

Yam, K. L., \& Papadakis, S. E. (2004). A Simple Digital Imaging Method for Measuring and Analyzing Color of Food Surfaces. Journal of Food Engineering, 61(1 SPEC.), 137142. https://doi.org/10.1016/S02608774(03)00195-X

Yuliawaty, S. T., \& Susanto, W. H. (2015). Pengaruh Lama Pengeringan dan Konsentrasi Maltodekstrin Terhadap Karakteristik Fisik Kimia dan Organoleptik Minuman Instan Daun Mengkudu (Morinda citrifolia L). Jurnal Pangan Dan Agroindustri, 3(1), 41-51. 


\section{AUTHOR GUIDELINES}

\section{Term and Condition}

1. Types of paper are original research or review paper that relevant to our Focus and Scope and never or in the process of being published in any national or international journal

2. Paper is written in good Indonesian or English

3. Paper must be submitted to http://journal.trunojoyo.ac.id/agrointek/index and journal template could be download here.

4. Paper should not exceed 15 printed pages (1.5 spaces) including figure(s) and table(s)

\section{Article Structure}

1. Please ensure that the e-mail address is given, up to date and available for communication by the corresponding author

2. Article structure for original research contains

Title, The purpose of a title is to grab the attention of your readers and help them decide if your work is relevant to them. Title should be concise no more than 15 words. Indicate clearly the difference of your work with previous studies.

Abstract, The abstract is a condensed version of an article, and contains important points ofintroduction, methods, results, and conclusions. It should reflect clearly the content of the article. There is no reference permitted in the abstract, and abbreviation preferably be avoided. Should abbreviation is used, it has to be defined in its first appearance in the abstract.

Keywords, Keywords should contain minimum of 3 and maximum of 6 words, separated by semicolon. Keywords should be able to aid searching for the article. Introduction, Introduction should include sufficient background, goals of the work, and statement on the unique contribution of the article in the field. Following questions should be addressed in the introduction: Why the topic is new and important? What has been done previously? How result of the research contribute to new understanding to the field? The introduction should be concise, no more than one or two pages, and written in present tense.

Material and methods, "This section mentions in detail material and methods used to solve the problem, or prove or disprove the hypothesis. It may contain all the terminology and the notations used, and develop the equations used for reaching a solution. It should allow a reader to replicate the work"

Result and discussion, "This section shows the facts collected from the work to show new solution to the problem. Tables and figures should be clear and concise to illustrate the findings. Discussion explains significance of the results."

Conclusions, "Conclusion expresses summary of findings, and provides answer to the goals of the work. Conclusion should not repeat the discussion." 
Acknowledgment, Acknowledgement consists funding body, and list of people who help with language, proof reading, statistical processing, etc.

References, We suggest authors to use citation manager such as Mendeley to comply with Ecology style. References are at least 10 sources. Ratio of primary and secondary sources (definition of primary and secondary sources) should be minimum 80:20.

Journals

Adam, M., Corbeels, M., Leffelaar, P.A., Van Keulen, H., Wery, J., Ewert, F., 2012. Building crop models within different crop modelling frameworks. Agric. Syst. 113, 57-63. doi:10.1016/j.agsy.2012.07.010

Arifin, M.Z., Probowati, B.D., Hastuti, S., 2015. Applications of Queuing Theory in the Tobacco Supply. Agric. Sci. Procedia 3, 255261.doi:10.1016/j.aaspro.2015.01.049

Books

Agrios, G., 2005. Plant Pathology, 5th ed. Academic Press, London. 